\title{
Lime and phosphate application as mycorrhizae stimulation to enhance growth and yield of Marandu grass
}

\section{Calagem e fosfatagem associadas a estimulante de micorrização no crescimento e produção do capim-Marandu}

\author{
Franklin Eduardo Melo Santiago ${ }^{1 *}$; Júlio César Azevedo Nóbrega ${ }^{2}$; Flávia \\ Louzeiro de Aguiar Santiago ${ }^{3}$; Ricardo Loiola Edvan; Rafaela Simão Abrahão \\ Nóbrega $^{2}$; Fatima Maria de Souza Moreira ${ }^{5}$
}

\begin{abstract}
Pastures are important food sources for Brazilian cattle herds. However, inadequate management of soil fertility has emerged as a major cause of low yield rates and of progressive degradation of these areas. The objective of the present study was to evaluate growth, by means of morphogenetic and structural characteristics, and yield of Brachiaria brizantha Stapf. cv. Marandu as functions of the application of the mycorrhizae stimulant formononetin, associated with lime and phosphate application. The experimental design was completely randomised with four replications, and the treatments were arranged in a $2 \times 2 \times$ 5 factorial scheme, consisting of two liming treatments (with and without limestone), two formononetin treatments (with and without application) and five $\mathrm{P}_{2} \mathrm{O}_{5}$ doses $\left(0,25,50,100\right.$ and $\left.200 \mathrm{mg} \mathrm{dm}^{-3}\right)$. Three shoot cuttings were carried out after a first standardisation cutting to evaluate the morphogenetic and structural characteristics as well as the dry matter yield of different morphological fractions. Liming and phosphate application at the dose of $141 \mathrm{mg} \mathrm{dm}^{-3} \mathrm{P}_{2} \mathrm{O}_{5}$ increased growth and yield of Marandu grass, and these practices are essential for the cultivation of this pasture grass in Yellow Latosol of the Cerrado region of Piauí, Brazil. The application of formononetin increased stem elongation rate, total number of tillers and green stem dry matter, and decreased dead dry matter of Marandu grass, which are effects that contribute to the improvement of pasture quality.
\end{abstract}

Key words: Brachiaria brizantha. Mycorrhizae. Pastures. Soil acidity.

\section{Resumo}

As pastagens constituem importante fonte alimentar para os rebanhos brasileiros, entretanto, o manejo inadequado da fertilidade dos solos têm-se destacado como uma das principais causas dos baixos índices produtivos e da progressiva degradação destas áreas. O objetivo do presente estudo foi avaliar o crescimento, através das características morfogênicas e estruturais, e a produção da Brachiaria brizantha Stapf. cv. Marandu em função da aplicação do estimulante de micorrização formononetina associado

1 Prof. M.e, Curso de Engenharia Agronômica, Instituto Federal do Piauí, IFPI, Campus Uruçuí, Uruçuí, PI, Brasil. E-mail: franklin.santiago@hotmail.com.br

2 Profs. Drs., Centro de Ciências Agrárias, Ambientais e Biológicas, Universidade Federal do Recôncavo da Bahia, UFRB, Cruz das Almas, BA, Brasil. E-mail: jcanobrega@gmail.com; rafaela.nobrega@gmail.com

3 Discente, Curso de Doutorado do Programa de Pós-Graduação em Ciência do Solo, Departamento de Ciência do Solo, Universidade Federal de Lavras, UFLA, Lavras, MG, Brasil. E-mail: flavia-lo-uzeiro@hotmail.com

4 Prof. Dr., Departamento de Zootecnia, Universidade Federal do Piauí, UFPI, Campus Prof Cinobelina Elvas, Bom Jesus, PI, Brasil. E-mail: agroloiola@gmail.com

5 Prof ${ }^{a}$ Dr $^{\mathrm{a}}$, Departamento de Ciência do Solo, UFLA, Lavras, MG, Brasil. E-mail: fmoreira@dcs.ufla.br

"Author for correspondence

Received: Aug. 18, 2016 Approved: Nov. 17, 2016 
a calagem e a fosfatagem. O delineamento experimental adotado foi o inteiramente casualizado, com quatro repetições, sendo os tratamentos dispostos num esquema fatorial $2 \times 2 \times 5$, constituídos por dois tratamentos de calagem (com e sem calcário), dois de formononetina (com e sem aplicação) e cinco doses de $\mathrm{P}_{2} \mathrm{O}_{5}\left(0,25,50,100\right.$ e $\left.200 \mathrm{mg} \mathrm{dm}^{-3}\right)$. Foram realizados três cortes da parte aérea, após um primeiro corte de uniformização, para realização das avaliações das características morfogênicas e estruturais, bem como a produção de massa seca das diferentes frações morfológicas. A calagem e a fosfatagem na dose de $141 \mathrm{mg} \mathrm{dm}^{-3}$ de $\mathrm{P}_{2} \mathrm{O}_{5}$ incrementaram o crescimento e a produção do capimMarandu, devendo ser práticas indispensáveis ao cultivo desta forrageira em Latossolo Amarelo do Cerrado piauiense, Brasil. A aplicação de formononetina promoveu aumento da taxa de alongamento do colmo, número total de perfilho, massa seca de colmo verde e diminuiu a fração da massa seca morta do capim-Marandu, efeitos que contribuem para a melhoria da qualidade das pastagens.

Palavras-chave: Brachiaria brizantha. Micorrizas. Pastagens. Acidez do solo.

\section{Introduction}

Brazil is a major agricultural producer, with a focus on dairy and meat production on pastures. Pastures are important food sources for the herds, offering abundant nutrients at low costs compared to concentrated feed, thereby allowing high competitiveness on the international market. However, the Brazilian cattle industry is still marked by low yield and profitability, mainly because of a poor management of the soil-animal-forage system, characterized mostly by an extractive exploitation model.

The lack of management of soil fertility under pasture in Brazil stands out as one of the limiting factors of production of forage plants, mainly in low fertility soils characterized by high acidity, toxic levels of aluminium (Al) and manganese (Mn) and in soils poor in nutrients, especially phosphorus (P) (LOPES; GUIMARÃES GUILHERME, 2016). Thus, to maintain the productivity of these pasture, significant applications of lime and fertilisers are necessary, otherwise low bearing capacity and accelerated degradation are the consequences (FABRICE et al., 2015).

The complex dynamics of $\mathrm{P}$ in these soils, involving its fixation to mineral colloids, increases its deficiency, which besides compromising the nutritional value of forage, reduces the establishment and the productive capacity of pastures (NOVAIS; SMYTH, 1999), since P plays an important role in tillering and root development of forage grasses (MALAVOLTA, 2006). Phosphate is therefore essential in pasture systems and generally depends on the application of $\mathrm{P}$ doses at levels above those required by the cultivation, which makes Brazil a large consumer of $P$ fertilisers (RESENDE; FURTINI NETO, 2007). Thus, the search for management strategies to increase the efficiency of phosphorus fertilisation is crucial due to the association between the growing demand for phosphate fertilisers, the costs of product acquisition and the finite reserves of phosphate rock.

Arbuscular mycorrhizae (AM) are a symbiosis between most plants and arbuscular mycorrhizal fungi (AMF), in which the plant benefits from the absorption of water and nutrients provided by the fungal hyphae, while fungus receives photosynthetic assimilates. This symbiosis provides numerous benefits to crops, such as nodulation and biological nitrogen fixation in legume species (JESUS et al., 2005) and increases tolerance to abiotic stress, toxicity and heavy metals (KLAUBERG FILHO et al., 2005). However, the nutritional effects of AM on plants are more evident and consistent and determine their biofertiliser character, since the hyphae and the mycelium of the fungus extend the exploitation zone of the root system, enhancing the uptake of water and nutrients, especially those of low mobility in the soil, such as copper $(\mathrm{Cu})$, zinc (Zn) and P (NOGUEIRA; CARDOSO, 2006). 
Mycorrhizae can increase $\mathrm{P}$ absorption up to 80\% (MARSCHNER; DELL, 1994). This process is more significant in the soils of the Brazilian Cerrado with low P levels, which is a condition that stimulates the establishment of mycorrhizae (BALOTA et al., 2012). Costa et al. (2012) studied the effect of arbuscular mycorrhizae on the growth and nutritional status of Brachiaria brizantha cv. Marandu and found that inoculation of mycorrhizal fungi significantly influenced dry matter yields and macronutrient absorption. However, the production of AMF inoculum on a large scale is still a limiting factor for their management in view of the biotrophic character of these fungi. Nevertheless, plant mycorrhization stimulation by native fungi has emerged as a promising alternative for their appropriate management and is aimed at increasing crop yields.

In this context, formononetin is active in AMF propagules, stimulates fungal growth and induces the morphological formation and differentiation, increasing the formation of appressoria and points of primary inputs (NAIR et al., 1991). Thus, it is expected that the application of this substance in grain and forage crops, among others, maximizes the activity of soil indigenous fungi (SILVA-JÚNIOR; SIQUEIRA, 1997), resulting in higher plant yields. Studies carried out by Novais and Siqueira (2009), who applied Mycoform ${ }^{\circledR}$, the basis of the isoflavonoid formononetin, AMF colonization and sporulation in Brachiaria decumbens were increased.

Therefore, the aim of this study was to evaluate growth, by means of morphogenetic and structural characteristics, and yield of Brachiaria brizantha Stapf. cv. Marandu as a function of the application of the mycorrhization stimulant formononetin associated with liming and phosphate.

\section{Material and Methods}

The experiment was carried out in a nursery with $50 \%$ luminosity, average temperatures of $34^{\circ} \mathrm{C}$ and relative humidity of $51 \%$, at the Federal University of Piauí, Campus Bom Jesus, Brazil, from June to December 2013.

Experimental units consisted of pots filled with $3 \mathrm{dm}^{3}$ samples of a Yellow Latosol (Oxisol), loam sandy texture (clay: 762 ; silt: 50 ; and sand: $188 \mathrm{~g} \mathrm{~kg}^{-1}$ ), collected at a depth of 0 to $0.20 \mathrm{~m}$ in native cerrado forest, with the following chemical characteristics: $\mathrm{pH} \mathrm{H}_{2} \mathrm{O}-4.2$; organic matter - 15.2 $\mathrm{g} \mathrm{kg}^{-1} ; \mathrm{P}-0.4 \mathrm{mg} \mathrm{dm}{ }^{-3} ; \mathrm{K}-37.5 \mathrm{mg} \mathrm{dm}{ }^{-3} ; \mathrm{Ca}-0.2$ $\mathrm{cmol}_{\mathrm{c}} \mathrm{dm}^{-3} ; \mathrm{Mg}-0.1 \mathrm{cmol}_{\mathrm{c}} \mathrm{dm}^{-3} ; \mathrm{Al}-1.0 \mathrm{cmol}_{\mathrm{c}} \mathrm{dm}^{-}$ 3; $\mathrm{H}+\mathrm{Al}-4.1 \mathrm{cmol}_{\mathrm{c}} \mathrm{dm}^{-3} ; \mathrm{CTC}-4.5 \mathrm{cmol}_{\mathrm{c}} \mathrm{dm}^{-3} ; \mathrm{m}$ $-71.6 \%$.

The experimental design was completely randomised with four replications, and the treatments were arranged in a $2 \times 2 \times 5$ factorial scheme, consisting of two liming treatments (with and without limestone), two formononetin treatments (with and without application) and five $\mathrm{P}_{2} \mathrm{O}_{5}$ doses $(0,25,50,100$ and $200 \mathrm{mg}$ $\mathrm{dm}^{-3}$ ) in the form of simple superphosphate. Formononetin (7-hydroxy-4'-methoxy-isoflavone), in the commercial form Myconate ${ }^{\circledR}$ (Plant Health Care (PHC), INC-Pittsburg, USA), was applied at the dose of $2 \mathrm{mg} \mathrm{dm}^{-3}$ soil, according to the manufacturer's recommendation. The treatment subjected to liming was calculated to increase base saturation to $45 \%$, as required by Brachiaria brizantha Stapf. cv. Marandu, according to Vilela et al. (2004), corresponding to the application of $2.8 \mathrm{~g}$ per pot of filler type dolomitic limestone with $\mathrm{PRNT}=94 \%$. For limestone reaction, soil remained 30 days incubated under field capacity.

Sowing was carried out using 10 seeds per pot, with subsequent thinning at 10 days after the emergence, leaving only four plants per pot. Three shoot cuttings were carried out after a first standardisation cutting at regular intervals of 45 days. The first and the second cuttings were made at $0.05 \mathrm{~m}$ height from the ground and the third cutting close to the ground.

During planting, basic fertilisation was 
carried out with the application of phosphate, according to the treatments, and with a cocktail of micronutrients consisting of boron (B), copper $(\mathrm{Cu})$, zinc $(\mathrm{Zn})$ and molybdenum $(\mathrm{Mo})$, at the doses of $0.5,1.0,1.0$ and $0.1 \mathrm{mg} \mathrm{dm}^{-3}$, respectively (VILELA et al., 2004). The sources used were reagent P.A.: $\mathrm{H}_{3} \mathrm{BO}_{3}, \mathrm{CuSO}_{4} .5 \mathrm{H}_{2} \mathrm{O}, \mathrm{ZnSO}_{4} 7 \mathrm{H}_{2} \mathrm{O}$ and $\left(\mathrm{NH}_{4}\right)_{6} \mathrm{Mo}_{7} \mathrm{O}_{24}$. Application of nitrogen and potassium was carried out by solution, split in three topdressing fertilisations for every cutting, with the first being applied after the standardisation cutting, using $20 \mathrm{mg} \mathrm{dm}^{-3}$ urea and $10 \mathrm{mg} \mathrm{dm}^{-3}$ potassium chloride (VILELA et al., 2004). Soil humidity was maintained at $70 \%$ of the total pore volume (TPV), controlled by daily weighing of the pots, replacing the evapotranspirated moisture with distilled water.

For evaluations of morphogenetic and structural characteristics, three tillers per pot were identified and marked with coloured nylon threads. Leaf blade and tiller stem were measured with the aid of a ruler. Data collection was carried out after the standardisation cutting until the third cutting.

Based on leaf and stem growth, the following variables were estimated: a) leaf appearance rate $\left(\mathrm{LAR}\right.$, day $^{-1}$ tiller $^{-1}$ ) - ratio between the number of expanded leaves per tiller and the number of days involved; b) phyllochron (PHY, days leaf ${ }^{-1}$ ) - inverse of LAR, obtained by the period of time for the full expansion of two consecutive leaves; c) leaf elongation rate (LER, $\left.\mathrm{mm} \mathrm{day}^{-1}\right)$ - difference between the initial and final length of each blade, divided by the number of days involved; d) leaf senescence rate $\left(\mathrm{LSR}, \mathrm{mm}\right.$ day $\left.^{-1}\right)$ - difference between the initial final length of the green tissue divided by the number of days involved (leaves were considered senescent when they presented more than 50\% yellowed blade); e) stem elongation rate $\left(\mathrm{SER}, \mathrm{mm}\right.$ day $^{-1}$ ) - difference between the initial and final length of the stems, divided by the number of days involved; f) duration of leaf elongation (DLE, days) - interval between leaf appearance leaf to the beginning of senescence; g) leaf life duration (LLD, days) - interval between leaf appearance to its full senescence (leaves were considered fully senescent when they presented less than $25 \%$ of green blade); h) total number of leaves per tiller (NLT, leaves tiller ${ }^{-1}$ ) -counting of the total number of green and senescent leaves; i) total number of live leaves per tiller (TNLL, leaves tiller ${ }^{-1}$ ) -counting of total number of leaves that presented no sign of senescence at the end of the evaluation period; $j$ ) total number of tillers per plant (NTP) -counting of the number of tillers per plant; $\mathrm{k}$ ) stem height $(\mathrm{SH}$, $\mathrm{cm}$ ) - length of the ligule of the last expanded leaf in relation to the insertion in the tiller of origin.

To quantify forage mass yield at every cutting, we morphologically separated the fractions into green leaf blade (ligule height), stem (stem + sheath) and dead material. The material was dried in a forced air circulation oven at $60^{\circ} \mathrm{C}$ until constant weight and subsequently weighted. Based on the morphological components, we estimated the parameters of yield of the different fractions of the plant by determining green blade dry matter (GBDM), green stem dry matter (GSDM), dead forage dry matter (DFDM), green forage dry matter (GFDM) and total forage dry matter (TFDM).

Data were subjected to analysis of variance using the statistical analysis system SISVAR, version 5.3 (FERREIRA, 2011). Means of liming and formononetin factors were compared by the Tukey test at $5 \%$ probability and $\mathrm{P}_{2} \mathrm{O}_{5}$ doses were subjected to polynomial regression analysis.

\section{Results and Discussion}

\section{Morphogenetic and structural characteristics}

Leaf appearance rate (LAR), phyllochron (PHY) and leaf elongation rate (LER) were not affected ( $p>$ $0.05)$ by any of the treatments. The non-significance of these parameters may be associated with the greater responsiveness to nitrogen fertilisation (ALEXANDRINO et al., 2004; MARTUSCELLO et al., 2005; RODRIGUES et al., 2012) compared 
to phosphorus fertilisation. We therefore assume that the nitrogen fertiliser applied to each cutting added to the amount of mineralized $\mathrm{N}$ of the soil, but was not sufficient to promote initial leaf growth with the increase of phosphorus fertilization in the establishment ofin Marandu grass.

Liming reduced leaf senescence rate (LSR) in $44 \%$ (Table 1). In contrast, the application of $\mathrm{P}_{2} \mathrm{O}_{5}$ doses promoted a linear increase, with a maximum value of $5.35 \mathrm{~mm}^{-1 a y}{ }^{-1}$ at the dose of $200 \mathrm{mg} \mathrm{dm}^{-3} \mathrm{P}_{2} \mathrm{O}_{5}$ (Figure 1a). Leaf senescence is a natural process that characterises the last stage of leaf development, which starts after full expansion, and can be accelerated by environmental factors such as competition for light, water and nutrients (LEMAIRE et al., 2011). Thus, only liming decreases the toxicity of $\mathrm{Al}^{3+}$ and $\mathrm{Mn}^{2+}$ and increases the levels of $\mathrm{Ca}^{2+}$ and $\mathrm{Mg}^{2+}$, delaying leaf senescence and, consequently, increasing the period with live or green leaves, which are the most nutritious fractions of the plant for animal diet. In contrast, phosphorus fertilisation by injection of energetic compounds accelerates metabolism and physiological processes in the tissue flow with the emergence and/or growth of new leaves (COSTA et al., 2016) and is therefore essential for pasture recovery.

Table 1. Leaf senescence rate (LSR), total number of live leaves per tiller (TNLL), total number of leaves per tiller (NLT), stem height (SH), green blade dry matter (GBDM), green forage dry matter (GFDM), total forage dry matter (TFDM) and dead forage dry matter (DFDM) of Marandu grass as a function of lime.

\begin{tabular}{|c|c|c|c|c|c|c|c|c|c|}
\hline \multirow{2}{*}{ Treatment } & \multirow{2}{*}{ LRS } & \multirow{2}{*}{ TNLL } & \multirow{2}{*}{ NLT } & \multirow{2}{*}{$\mathrm{SH}$} & GBDM & GFDM & TFDM & \multicolumn{2}{|c|}{ DFDM } \\
\hline & & & & & \multicolumn{3}{|c|}{----------1st cutting------- } & 2nd cutting & 3rd cutting \\
\hline & $\mathrm{mm}$ day $^{-1}$ & & & $\mathrm{~cm}$ & \multicolumn{5}{|c|}{ 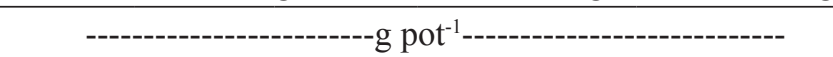 } \\
\hline Without lime & $5.07 \mathrm{a}$ & $1.88 \mathrm{~b}$ & $2.95 \mathrm{~b}$ & $7.33 \mathrm{~b}$ & $1.73 \mathrm{~b}$ & $2.09 \mathrm{~b}$ & $2.50 \mathrm{~b}$ & $0.69 \mathrm{~b}$ & $1.67 \mathrm{~b}$ \\
\hline With lime & $2.83 \mathrm{~b}$ & $2.34 \mathrm{a}$ & $3.35 \mathrm{a}$ & $8.10 \mathrm{a}$ & $2.33 \mathrm{a}$ & $2.75 \mathrm{a}$ & $3.22 \mathrm{a}$ & $0.86 \mathrm{a}$ & $2.50 \mathrm{a}$ \\
\hline
\end{tabular}

Means followed by the same letter do not differ by the Tukey test at $5 \%$ probability.

In terms of stem elongation rate (SER) and the interaction between the doses of $\mathrm{P}_{2} \mathrm{O}_{5}$ and formononetin, we observed a quadratic behaviour when the stimulant was applied, with a maximum rate of $0.84 \mathrm{~mm} \mathrm{day}^{-1}$ at the dose of $109 \mathrm{mg} \mathrm{dm}^{-3}$ $\mathrm{P}_{2} \mathrm{O}_{5}$, while in the absence of the stimulant, SER presented a linear increase (Figure 2a). In regards to the interaction between $\mathrm{P}_{2} \mathrm{O}_{5}$ doses and liming, there was a linear increase with liming and quadratic adjustment in the absence of liming, with a maximum value of $0.74 \mathrm{~mm} \mathrm{day}^{-1}$ at the dose of $118 \mathrm{mg} \mathrm{dm}^{-3} \mathrm{P}_{2} \mathrm{O}_{5}$ (Figure 2b). Since liming increases soil fertility, it provides direct benefits to the growth of grasses due to the more efficient use of fertilisers, such as phosphate; on the other hand, the application of formononetin for mycorrhizae stimulation favours plant growth by the increase of water and nutrients absorption due to the higher soil volume explored by mycorrhizal roots (NOVAIS; SIQUEIRA, 2009).

The mean value of LER (5.07 mm day ${ }^{-1}$ ) was about six times higher than the mean value of SER with the application of liming $\left(0.89 \mathrm{~mm}^{-1 a y}{ }^{-1}\right)$ and formononetin $\left(0.84 \mathrm{~mm} \mathrm{day}{ }^{-1}\right)$ as a function of $\mathrm{P}_{2} \mathrm{O}_{5}$, showing the great potential of Marandu grass for leaf yield in relation to stem yield. This is a desirable characteristic of pastures, since leaf blade is a morphological component of high nutritional value. Positive responses to $\mathrm{P}$ doses in terms of SER have been reported by Oliveira et al. (2013), who observed linear increases for doses of 0, 50, 70 and $90 \mathrm{~kg} \mathrm{ha}^{-1} \mathrm{P}_{2} \mathrm{O}_{5}$ in Brachiaria brizantha cv. Xaraés, increasing from 0.12 to $0.34 \mathrm{~cm} \mathrm{day}^{-1}$. 
Figure 1. Leaf senescence rate (LSR) (a), duration of leaf elongation (DLE) (b), leaf life duration (LLD) (c), total number of live leaves per tiller (TNLL) (d), total number of leaves per tiller (NLT) (e) and stem height (SH) (f) of Marandu grass as a function of phosphorus doses. ** and * significant at 1 and $5 \%$ probability.
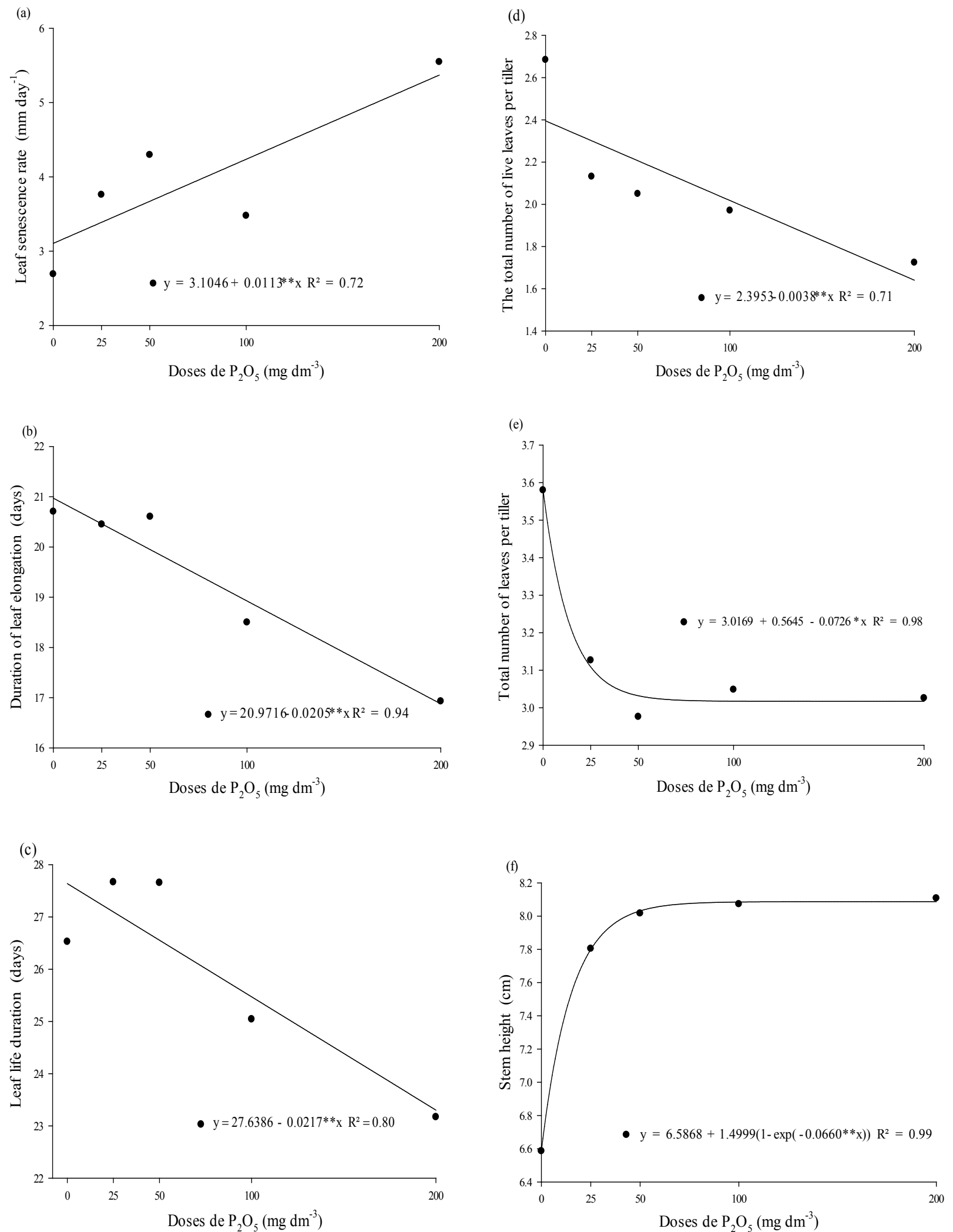
Figure 2. Stem elongation rate (SER) of Marandu grass in function of the phosphorus doses and of the application of formononetin (a) and lime (b). WOF: without formononetin; WF: with formononetin; WOL: without lime; WL: with lime. ${ }^{*}$ and $*$ significant at 1 and $5 \%$ probability.

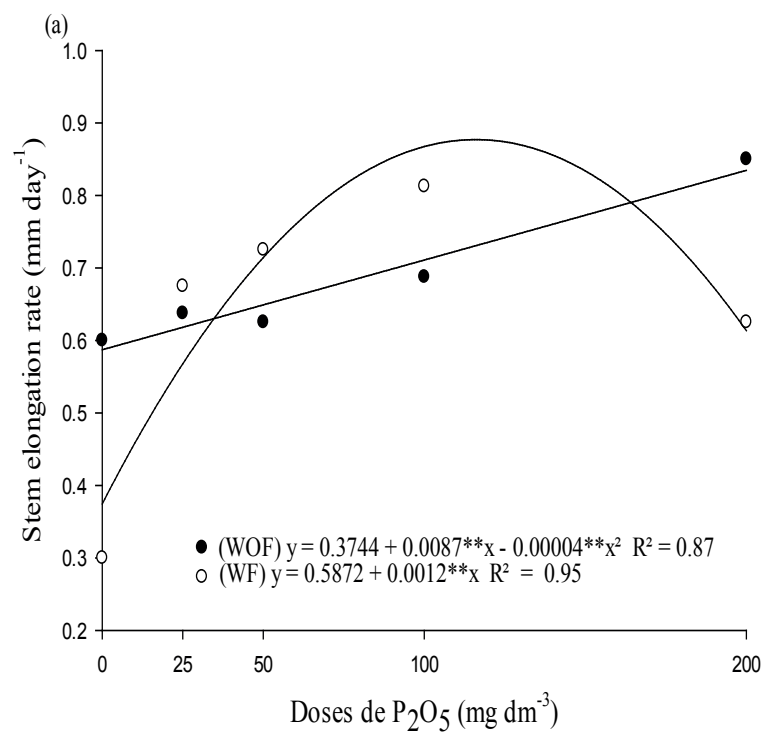

The increase of $\mathrm{P}_{2} \mathrm{O}_{5}$ doses promoted linear decreases in the duration of leaf elongation (DLE) and leaf life duration (LLD) (Figures $1 \mathrm{~b}$ and $\mathrm{c}$ ). Similar to LSR, phosphate fertilisers promote pasture recovery by reducing the durability of the leaf blade (NABINGER; CARVALHO, 2009).

For the total number of live leaves (TNLL) and the total number of leaves (NLT), liming increased leave emission of Marandu grass by 24 and 13\%, respectively (Table 1). In relation to $\mathrm{P}_{2} \mathrm{O}_{5}$ doses, we observed a different behaviour for both variables (Figure 1d and e). The TNLL presented a linear decrease with the increase in $\mathrm{P}_{2} \mathrm{O}_{5}$ doses (Figure 1d). On the other hand, NLT adjusted to the exponential model curve, decreased to $50 \mathrm{mg} \mathrm{dm}^{-3} \mathrm{P}_{2} \mathrm{O}_{5}$ and became constant at the other doses (Figure 1e). Although leaf number is a genetically determined characteristic, it can be influenced by several environmental factors, such as temperature, water conditions and nutrient availability (FULKERSON; SLACK, 1995), and the plant may reach its maximum number of leaves earlier. The mean NLT value for Marandu grass of 3.15 leaves tiller ${ }^{-1}$ is lower than that observed by Alexandrino et al.

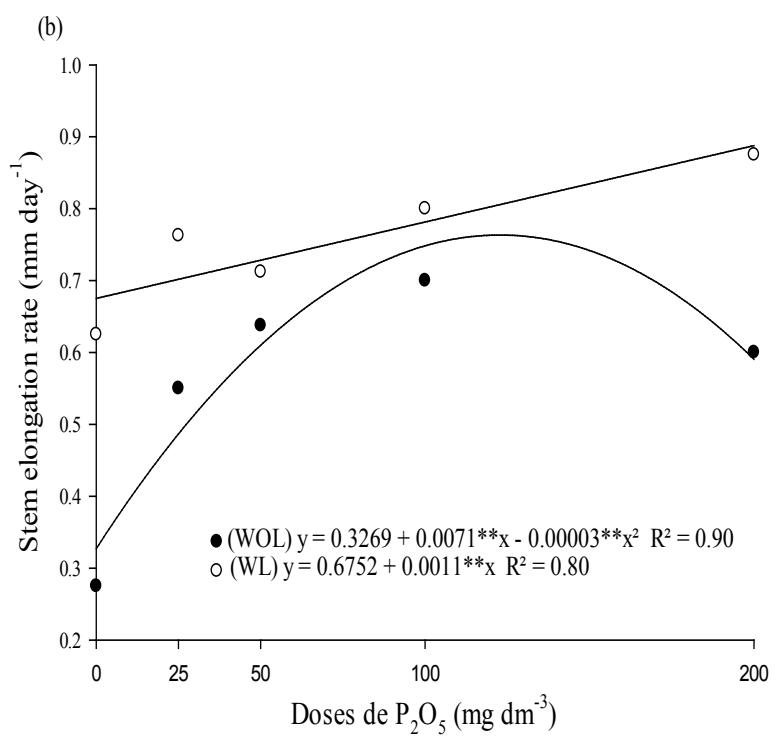

(2004) for the same culture, i.e., 6.7 leaves tiller-1 at an age of 45 days. Possibly, these values were higher since the authors worked with $\mathrm{N}$ doses that favour the appearance of leaves. The TNLL reflects the behaviour of LSR as a function of $\mathrm{P}_{2} \mathrm{O}_{5}$, since due to the intensification of the leave senescence process, TNLL becomes progressively lower than the total number of expanded leaves which, according to Gomide and Gomide (2000), tends to be closer to a constant value, depending on the species or cultivar.

The total number of tillers per plant (NTP) interacted with all factors, with a maximum density of 4.5 tillers in the treatment with liming and formononetin at the dose of $131 \mathrm{mg} \mathrm{dm}^{-3} \mathrm{P}_{2} \mathrm{O}_{5}$ (Figure $3)$. This result highlights the demand of this species for high soil fertility and the importance of liming and phosphorus fertilisation which, associated with mycorrhiza, can promote tillering of forage grasses, which is one of the most important characteristic for pasture perennity and establishment (FERREIRA et al., 2008). Positive responses of tillering to phosphorus fertilisation have been widely reported in the literature (MESQUITA et al., 2005, 2010; GUEDES et al., 2009; RODRIGUES et al., 2012). 
Figure 3. Total number of tillers per plant (NTP) of Marandu grass as a function of lime, phosphorus doses and formononetin. WOF: without formononetin; WF: with formononetin; WOL: without lime; WL: with lime. ** significant at $1 \%$ probability.

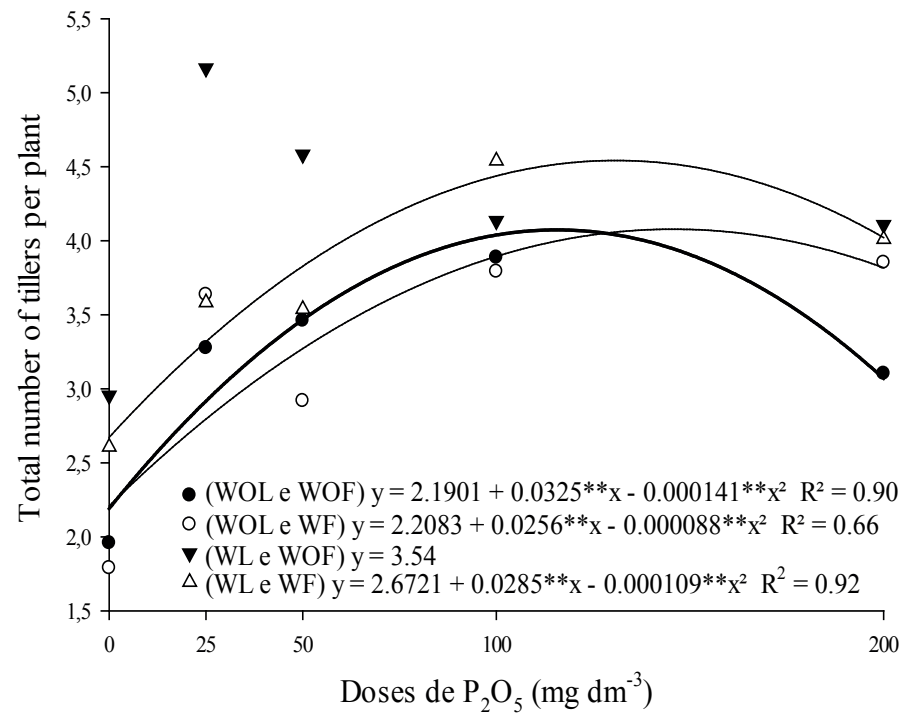

For stem height (SH) of Marandu grass, liming provided the highest mean values (Table 1). Similar results have been observed by Prado and Barion (2009), who found increments in the height of Tifton 85 grass (Cynodon sp.) with the application of increasing doses of liming $(0,1.55,2.32$ and 3.10 $\mathrm{g} \mathrm{dm}^{-3}$ ). On the other hand, the $\mathrm{P}_{2} \mathrm{O}_{5}$ doses influenced $\mathrm{SH}$ with exponential adjustment, which increased to the dose of $50 \mathrm{mg} \mathrm{dm}^{-3} \mathrm{P}_{2} \mathrm{O}_{5}$ (Figure 1f). Adequate $\mathrm{P}$ availability promotes plant growth, since this element constitutes energy compounds (ATP/ NADPH), phospholipids and other esters that have important functions in the plant (MALAVOLTA, 2006).

\section{Yield characteristics}

In the first cutting, green blade dry matter (GBDM) increased by $34 \%$ with liming (Table 1 ). In contrast, $\mathrm{P}_{2} \mathrm{O}_{5}$ presented quadratic behaviour for this variable, with a maximum increment of $2.84 \mathrm{~g}$ pot $^{-1}$ at the dose of $132 \mathrm{mg} \mathrm{dm}^{-3} \mathrm{P}_{2} \mathrm{O}_{5}$ (Figure 4a).
In the second and third cuttings (Figures $4 \mathrm{~b}$ and c), GBDM presented quadratic adjustment for the interaction between $\mathrm{P}_{2} \mathrm{O}_{5}$ doses and liming, and the highest yield was obtained with liming at doses of 162 and $151 \mathrm{mg} \mathrm{dm}^{-3} \mathrm{P}_{2} \mathrm{O}_{5}$, respectively. The increment in green leaf dry matter yield provided by liming in Marandu grass is due to soil acidity correction, which increases cation exchange capacity, nutrient availability and fertilisers efficiency. In the present study, liming increased the benefit of phosphorus fertilisation by 45 and $30 \%$ in the second and third cuttings, respectively, thereby contributing to pasture quality since leaf blades are the morphological parts of forage grasses with the highest crude protein content and are thus preferred by grazing animals (CECATO et al., 2014). These results corroborate those found by Teles et al. (2011) and Oliveira et al. (2012), who observed positive responses in GBDM yield of Brachiaria brizantha cv. MG-4 and Panicum maximum cv. Mombaça, respectively, with increasing $\mathrm{P}_{2} \mathrm{O}_{5}$ doses. 
Figure 4. Green blade dry matter (GBDM) (a, b and c) and green stem dry matter (GSDM) (c, d and f) of Marandu grass as a function of lime, phosphorus doses and formononetin. WOF: without formononetin; WF: with formononetin; WOL: without lime; WL: with lime. ns: not significant. ** and * significant at 1 and $5 \%$ probability.
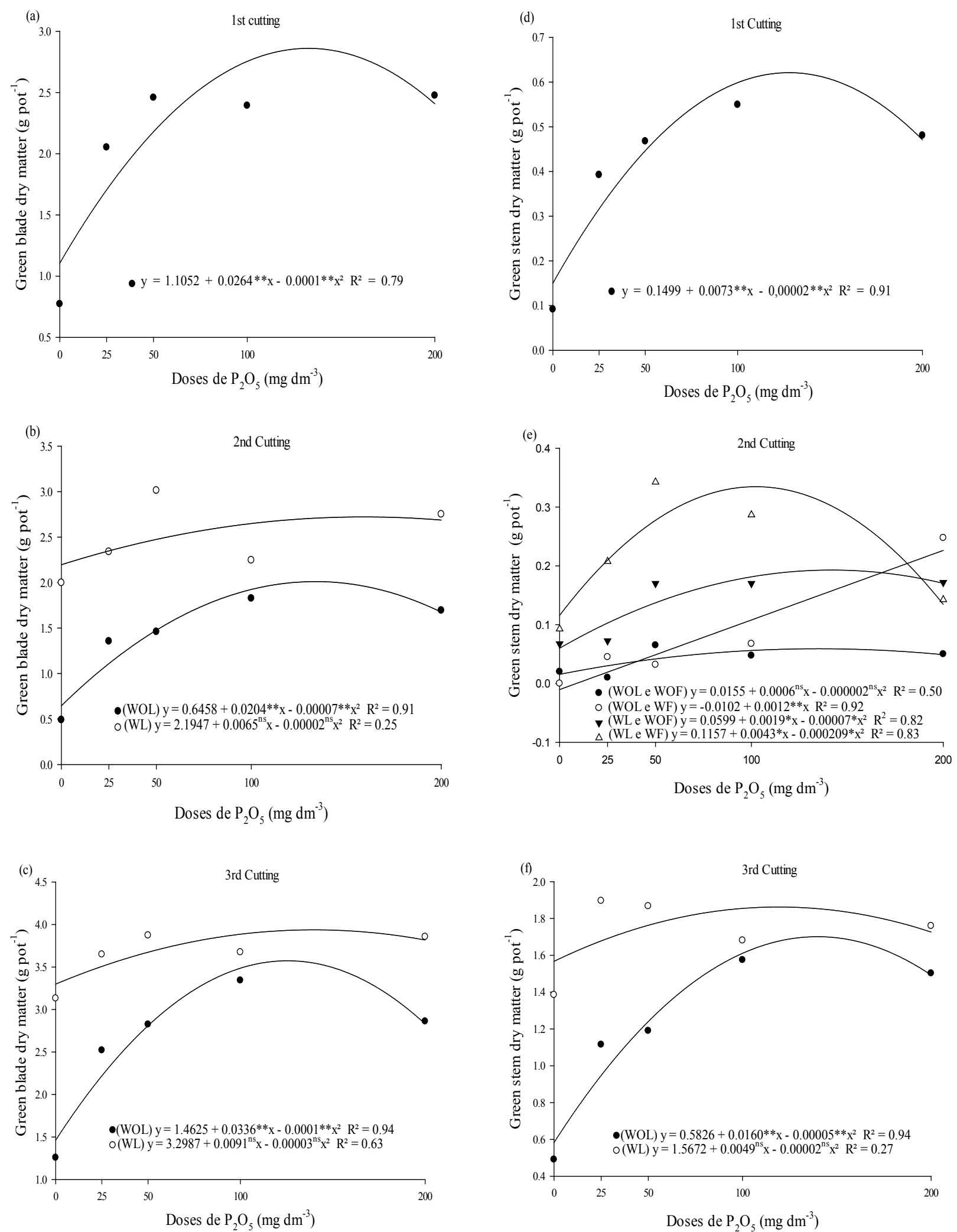
Dead forage dry matter yield (DFDM) was reduced by $29 \%$ with formononetin application in the second cutting (Table 2). On the other hand, liming increased this variable by 24 and $49 \%$, respectively, in the second and third cuttings (Table 1). For $\mathrm{P}_{2} \mathrm{O}_{5}$ doses in the three cuttings, DFDM presented a quadratic behaviour, with maximum yields at the doses of 150,187 and $150 \mathrm{mg} \mathrm{dm}^{-3} \mathrm{P}_{2} \mathrm{O}_{5}$ for the first, second and third cuttings, respectively (Figure 5). The increase in DFDM can be attributed to liming, while the increase in the emission of new leaves and tillers can be attributed to $\mathrm{P}_{2} \mathrm{O}_{5}$ doses, which in turn increased the competition for yield factors, such as light, nutrients and water, intensifying the senescence process and death of older leaves and tillers.

Table 2. Dead forage dry matter (DFDM) of Marandu grass as a function of formononetin addition in the second cutting.

\begin{tabular}{cc}
\hline Treatment & DFDM \\
\hline & g pot $^{-1}$ \\
Without formononetin & $0.87 \mathrm{a}$ \\
With formononetin & $0.67 \mathrm{~b}$ \\
\hline
\end{tabular}

Means followed by the same letter do not differ by Tukey test at $5 \%$ probability.

Figure 5. Dead forage dry matter (DFDM) of Marandu grass as a function of phosphorus doses. ** and * significant at 1 and $5 \%$ probability.

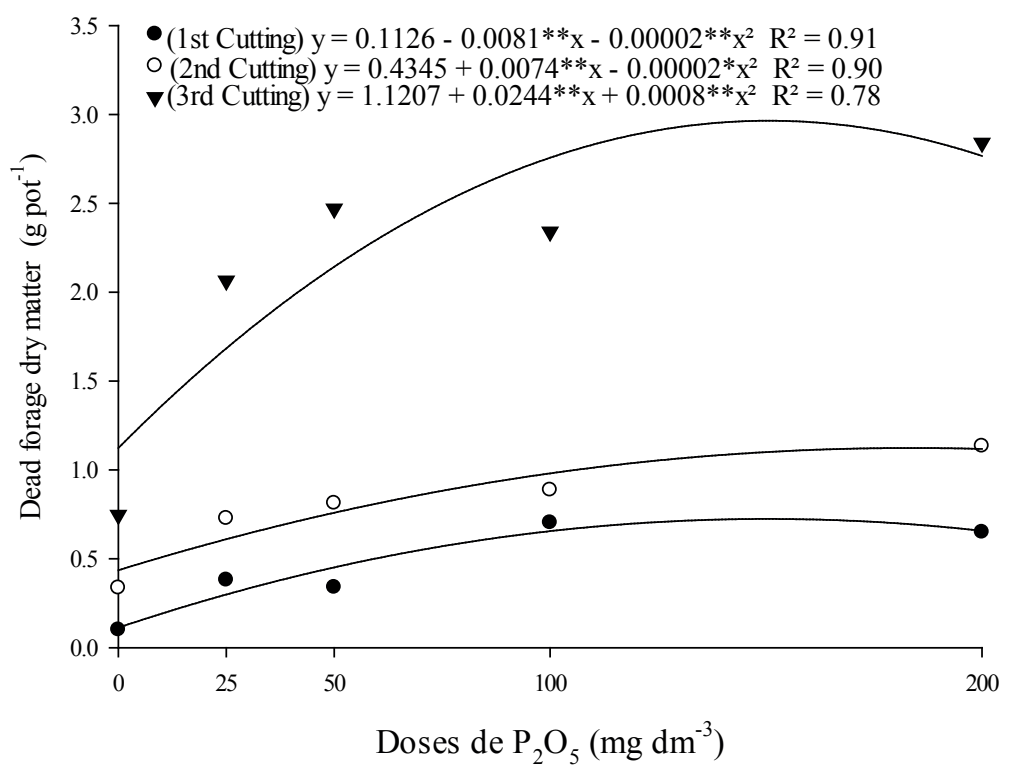

For green forage dry matter (GFDM), there was an increase of $31 \%$ with liming in the first cutting (Table 1) and a quadratic effect for $\mathrm{P}_{2} \mathrm{O}_{5}$ doses, with a maximum increase at the dose of $131 \mathrm{mg} \mathrm{dm}^{-3}$ $\mathrm{P}_{2} \mathrm{O}_{5}$ (Figure 6a). In the second and third cuttings, there was a quadratic adjustment for the interaction between the $\mathrm{P}_{2} \mathrm{O}_{5}$ doses and liming, demonstrating that liming led to maximum increments at doses of 148 and $131 \mathrm{mg} \mathrm{dm}^{-3} \mathrm{P}_{2} \mathrm{O}_{5}$, respectively (Figures $6 \mathrm{~b}$ and c). It should be noted that GFDM is an important yield parameter, since it qualitatively considers only green or living fractions of the plant, i.e., the most nutritious parts, confirming once again the importance of liming associated with phosphorus fertilisation for higher yields when pastures are cultivated in low fertility soils, such as the Yellow Latosol of the Cerrado region of the state of Piaui. 
Figure 6. Green forage dry matter (GFDMM) ( $a, b$ and $c$ ) and total forage dry matter (TFDM) (c, d and f) of Marandu grass as a function of lime and phosphorus doses. WOL: without lime; WL: with lime. ns: not significant; ** and * significant at 1 and $5 \%$ probability.
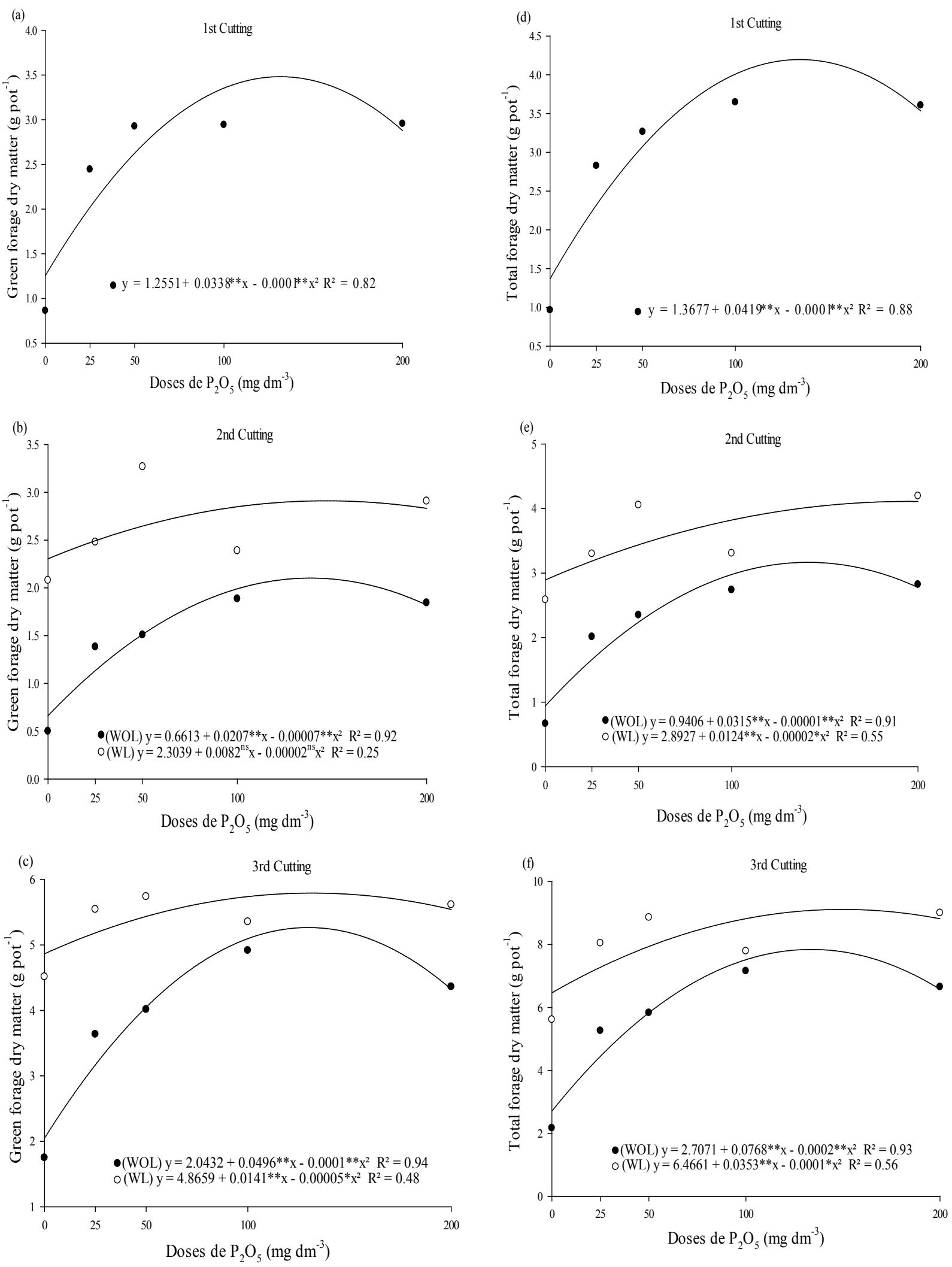
For total forage dry matter (TFDM), liming provided an increase of $28 \%$ in the first cutting (Table 1). On the other hand, $\mathrm{P}_{2} \mathrm{O}_{5}$ doses had a quadratic adjustment, with a maximum increment at the dose of $134 \mathrm{mg} \mathrm{dm}^{-3} \mathrm{P}_{2} \mathrm{O}_{5}$ (Figure 6d). The second and third cuttings presented quadratic behaviours for the interaction between $\mathrm{P}_{2} \mathrm{O}_{5}$ doses and liming (Figures $6 \mathrm{e}$ and $\mathrm{f}$ ), demonstrating that plants cultivated in the presence of lime achieve maximum values of 4.10 and $9.11 \mathrm{~g} \mathrm{pot}^{-1}$ at doses of 194 and $149 \mathrm{mg} \mathrm{dm}^{-3} \mathrm{P}_{2} \mathrm{O}_{5}$, respectively. Thus, in the last two cuttings, liming promoted better use of phosphorus fertilisation in 39 and $31 \%$, respectively.

The rResults underline the importance of increasing soil fertility for the establishment and productive maintenance of Marandu grass, which can be achieved by liming and phosphorus fertilisation, reflecting the nutritional improvement of the plant with increments in growth and forage dry matter. The influence of liming and phosphorus fertilisation on the increase in dry matter yield has been verified by Mesquita et al. (2005) in three forage species (Panicum maximum cv. Mombaça, Brachiaria brizantha cv. Marandu and Andropogon gayanus cv. Planaltina).

The positive interaction of liming with $\mathrm{P}_{2} \mathrm{O}_{5}$ doses for GBDM, GSDM, GFDM and TFDM and the increase of these variables from the second cutting may be related to the increase in the reaction of limestone with the soil components over time, confirming their benefits in terms of soil acidity correction and $\mathrm{P}$ availability.

\section{Conclusion}

Liming and phosphate applications at the dose of $141 \mathrm{mg} \mathrm{dm}^{-3} \mathrm{P}_{2} \mathrm{O}_{5}$ increased growth and yield of Marandu grass. These practices are therefore essential for the cultivation of this pasture grass in Yellow Latosol of the Cerrado region of the state of Piauí.

Formononetin application increased stem elongation rate, total number of tillers and green stem dry matter, but decreased the fraction of dead forage dry matter of Marandu grass. These effects contribute to the improvement of pasture quality.

\section{Acknowledgements}

This research was funded by the "Conselho Nacional de Desenvolvimento Científico e Tecnológico" (CNPq/CT-Agro n ${ }^{\circ}$ 69/2009) and "Coordenação de Aperfeiçoamento de Pessoal de Nível Superior" (CAPES).

\section{References}

ALEXANDRINO, E.; NASCIMENTO JÚNIOR, D.; MOSQUIM, P. R.; JOSÉ, A.; ROCHA, F. C. Características morfogênicas e estruturais na rebrotação da Brachiaria brizantha cv. Marandu submetida a três doses de nitrogênio. Revista Brasileira de Zootecnia, Viçosa, MG, v. 33, n. 1, p. 1372-1379, 2004.

BALOTA, E. L.; MACHINESKI, O.; SCHERER, A. Mycorrhizal effectiveness on physic nut as influenced by phosphate fertilization levels. Revista Brasileira de Ciência do Solo, Viçosa, MG, v. 36, n. 1, p. 23-32, 2012.

CECATO, U.; IWAMOTO, B. S.; PELUSO, E. P.; MARI, G. C.; PEREIRA, V. V.; SAUTE, J. M. Animal performance on Tanzânia grass pasture intercropped with Estilozantes Campo Grande or fertilized with nitrogen. Tropical Grasslands, Cali, v. 2, n. 1, p. 29-30, 2014.

COSTA, N. D. L.; MORAES, A. de; CARVALHO, P. C. D. F.; MAGALHÃES, J. A. Acúmulo de forragem e morfogênese de Trachypogon plumosus sob níveis de fósforo. Publicações em Medicina Veterinária e Zootecnia, Maringá, v. 10, n. 5, p. 388-393, 2016.

COSTA, N. D. L.; PAULINO, V. T.; COSTA, R. S. C.; PEREIRA, R. G. D. A.; TOWNSEND, C. R.; MAGALHÁES, J. A. Efeito de micorrizas arbusculares sobre o crescimento e nutrição mineral de Brachiaria brizantha cv. Marandu. Ciencia Animal Brasileira, Goiânia, v. 13, n. 4, p. 406-411, 2012.

FABRICE, C. E. S.; SOARES FILHO, C. V.; PINTO, M. F.; PERRI, S. H. V.; CECATO, U.; MATEUS, G. P. Recuperação de pastagens de Brachiaria decumbens degradada com introdução de Stylosanthes e adubação fosfatada. Revista Brasileira de Saúde e Produção Animal, Salvador, v. 16, n. 4, p. 758-771, 2015. 
FERREIRA, D. F. SISVAR : a computer statistical analysis system. Ciencia e Agrotecnologia, Lavras, v. 35, n. 6, p. 1039-1042, 2011.

FERREIRA, E. M.; SANTOS, A. C.; ARAÚUJ, L. D. C.; CUNHA, O. F. R. Características agronômicas do Panicum maximum cv.Mombaça submetido a níveis crescentes de fósforo. Ciência Rural, Santa Maria, v. 38, n. 2, p. 484-491, 2008.

FULKERSON, W. J.; SLACK, K. Leaf number as a criterion for determining defoliation time for Lolium perenne: 2. Effect of defoliation frequency and height. Grass and Forage Science, Oxford, v. 50, n. 1, p. 16-20, 1995.

GOMIDE, C. A. M.; GOMIDE, J. A. Morfogênese de cultivares de Panicum maximum jacq. Revista Brasileira de Zootecnia, Viçosa, MG, v. 29, n. 2. p. 341-348, 2000.

GUEDES, E. M. S.; FERNANDES, A. R.; LIMA, E. V.; GAMA, M. A. P.; SILVA, A. L. P. Fosfato natural de Arad e calagem e o crescimento de Brachiaria brizanta em latossolo amarelo sob pastagem degradada na Amazônia. Revista de Ciências Agrárias/Amazonian Journal of Agricultural and Environmental Sciences, Belém, v. 52, n. 1, p. 117-129, 2009.

JESUS, E. D. C.; SCHIAVO, J. A.; FARIA, S. M. Dependence on arbuscular mycorrhizal fungi for nodulation and growth of tropical woody legume species. Revista Arvore, Viçosa, MG, v. 29, n. 4, p. 545-552, 2005.

KLAUBERG FILHO, O.; SIQUEIRA, J. O.; MOREIRA, F. M. S.; SOARES, C. R. F. S.; SILVA, S. Ecologia, função e potencial de aplicação de fungos micorrízicos arbusculares em condições de excesso de metais pesados. In: VIDAL-TORRADO, P.; ALLEONI, L. R. F.; COOPER, M.; SILVA, A. P.; CARDOSO, E. J. (Ed.). Tópicos em ciência do solo. Viçosa, MG: UFV: Sociedade Brasileira de Ciência do Solo, 2005. p. 85-144.

LEMAIRE, G.; HODGSON, J.; CHABBI, A. Grassland productivity and ecosystem services. Cabi: Wallingford, 2011. 312 p.

LOPES, A. S.; GUIMARÃES GUILHERME, L. R. A career perspective on soil management in the Cerrado region of Brazil. Advances in Agronomy, Newark, v. 137, n. 1, p. 1-72, 2016.

MALAVOLTA, E. Manual de nutrição mineral de plantas. São Paulo: Agronômica, 2006. 638 p.

MARSCHNER, H.; DELL, B. Nutrient uptake in mycorrhizal symbiosis. Plant and Soil, Crawley, v. 159, n. 1, p. 89-102, 1994.

MARTUSCELLO, J. A.; FONSECA, D. M.; NASCIMENTO JÚNIOR, D.; SANTOS, P. M.; RIBEIRO
JÚNIOR, J. I.; CUNHA, D. N. F. V.; MOREIRA, L. M. Características morfogênicas e estruturais do capimXaraés submetido à adubação nitrogenada e desfolhação. Revista Brasileira de Zootecnia, Viçosa, MG, v. 34, n. 5, p. 1475-1482, 2005.

MESQUITA, E. E.; NERES, M. A.; OLIVEIRA, P. S. R.; MESQUITA, L. P.; SCHNEIDER, F.; TEODORO JÚNIOR, J. R. Teores críticos de fósforo no solo e características morfogênicas de Panicum maximum cultivares Mombaça e Tanzânia-1 e Brachiaria híbrida Mulato sob aplicação de fósforo. Revista Brasileira de Saúde e Produção Animal, Salvador, v. 11, n. 2, p. 292302, 2010.

MESQUITA, E. E.; PINTO, J. C.; TAVARES, V. B.; SANTOS, I. P. A.; FURTINI NETO, A. E.; FARIA, D. J. G. Crescimento e produção de três gramíneas forrageiras em amostras de solo sob doses de fósforo. Pasturas Tropicales, Cali, v. 27, n. 3, p. 44-50, 2005.

NABINGER, C.; CARVALHO, P. C. F. Ecofisiología de sistemas pastoriles: aplicaciones para su sustentabilidad. Agrociência, San Luis Huexotla, v. 13, n. 3, p. 18-27, 2009.

NAIR, M. G.; SAFIR, G. R.; SIQUEIRA, J. O. Isolation and identification of vesicular-arbuscular mycorrhizastimulatory compounds from clover (Trifolium repens) roots. Applied and Environmental Microbiology, Washington, v. 57, n. 2, p. 434-439, 1991.

NOGUEIRA, M. A.; CARDOSO, E. J. B. N. Plant growth and phosphorus uptake in mycorrhizal rangpur lime seedlings under different levels of phosphorus. Pesquisa Agropecuaria Brasileira, Brasilia, v. 41, n. 1, p. 93-99, 2006.

NOVAIS, C. B.; SIQUEIRA, J. O. Aplicação de formononetina na colonização e esporulação de fungos micorrízicos em braquiária. Pesquisa Agropecuaria Brasileira, Brasília, v. 44, n. 5, p. 496-502, 2009.

NOVAIS, R. F.; SMYTH, T. J. Fósforo em solos e plantas em condições tropicais. Viçosa, MG: UFV, 1999, 399 p.

OLIVEIRA, P. S. R.; DEMINICIS, B. B.; CASTAGNARA, D. D.; GOMES, F. C. N. Efeito da adubação com fósforo do capim Mombaça em solos com texturas arenosa e argilosa. Archivos de Zootecnia, Córdoba, v. 61, n. 235, p. 397-406, 2012.

OLIVEIRA, W. L.; RODRIGUES, R. C.; PARENTE, H. N.; GALVÃO, C. M. L.; CARDOSO, S. S. S.; SOUSA, T. V. R.; ARAÚJO, I. G. R.; SILVA JÚNIOR, A. L. Características agronômicas, morfogênicas e estruturais do capim-Xaraés adubado com diferentes quantidades de fósforo. Revista Brasileira de Agropecuária Sustentável, Viçosa, v. 3, n. 2, p. 45-51, 2013. 
PRADO, R. D. M.; BARION, R. D. Efeitos da calagem na nutrição e produção de massa seca do capim Tifton 85 . Pesquisa Agropecuária Tropical, Goiânia, v. 39, n. 3, p. 218-224, 2009.

RESENDE, A. V.; FURTINI NETO, A. E. Aspectos relacionados ao manejo da adubação fosfatada em solos do cerrado. Planaltina: Serviço gráfico da EMBRAPA Cerrados, 2007. 30 p.

RODRIGUES, R. C.; LIMA, D. O. S.; CABRAL, L. S.; PLESE, L. P. M.; SCARAMUZZA, W. L. M. P.; UTSONOMYA, T. C. A.; JESUS, A. P. R. Produção e morfofisiologia do capim Brachiaria brizantha cv . Xaraés sob doses de nitrogênio e fósforo. Revista Brasileira de Agropeccuária Sustentável, Viçosa, MG, v. 2, n. 1, p. 124-131, 2012.

SIlVA, D. R. G.; COSTA, K. A. P.; FAQUIN, V.; OLIVEIRA, P. I.; BERNARDES, T. F. Doses e fontes de nitrogênio na recuperação das características estruturais e produtivas do capim-Marandu. Revista Ciencia Agronômica, Fortaleza, v. 44, n. 1, p. 184-191, 2013.
SILVA-JÚNIOR, J. P.; SIQUEIRA, J. O. Aplicação de formononetina sintética ao solo como estimulante da formação de micorriza no milho e na soja. Revista Brasileira de Fisiologia Vegetal, Campinas, v. 9, n. 1, p. 35-41, 1997.

TELES, T. G. R. M.; CARNEIRO, M. S. S.; SOARES, I.; PEREIRA, E. S.; SOUZA, P. Z.; MAGALHÃES, J. A. Produção e composição química da Brachiaria brizantha cv. MG-4 sob efeito de adubação com NPK. Acta Scientiarum - Animal Sciences, Maringá, v. 33, n. 2, p. 137-143, 2011.

VILELA, L.; SOARES, W. V.; SOUSA, D. M. G.; MACEDO, M. C. M. Calagem e adubação para pastagens. In: SOUSA, D. M. G.; LOBATO, E. (Ed.). Cerrado: correção do solo e adubação. Brasília: Embrapa Cerrados, 2004. p. 245-256. 